\title{
The epidemiological background of small ruminant lentivirus infection in goats from Romania
}

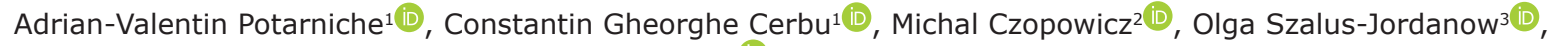 \\ Jaroslaw Kaba² ${ }^{2}$ and Marina Spinu ${ }^{1}$ \\ 1. Department of Infectious Diseases and Preventive Medicine, Faculty of Veterinary Medicine, University of Agricultural \\ Sciences and Veterinary Medicine Cluj-Napoca, Cluj, Romania; 2. Division of Veterinary Epidemiology and Economics, \\ Institute of Veterinary Medicine, Warsaw University of Life Sciences, Warsaw, Poland; 3. Department of Small Animal \\ Diseases with Clinic, Institute of Veterinary Medicine, Warsaw University of Life Sciences, Warsaw, Poland. \\ Corresponding author: Constantin Gheorghe Cerbu, e-mail: constantin.cerbu@usamvcluj.ro \\ Co-authors: AVP: adrian.potarniche@usamvcluj.ro,MC: michal_czopowicz@sggw.edu.pl,oS: olga_szalus@sggw.edu.pl, \\ JK: jaroslaw_kaba@sggw.edu.pl, MS: marina.spinu@usamvcluj.ro \\ Received: 07-03-2020, Accepted: 19-05-2020, Published online: 15-07-2020
}

doi: www.doi.org/10.14202/vetworld.2020.1344-1350 How to cite this article: Potarniche AV, Cerbu CG, Czopowicz M, Szalus-Jordanow O, Kaba J, Spinu M (2020) The epidemiological background of small ruminant lentivirus infection in goats from Romania, Veterinary World, 13(7): 1344-1350.

\begin{abstract}
Background and Aim: Caprine arthritis-encephalitis (CAE) is an economically significant viral disease of goats caused by a small ruminant lentivirus (SRLV) belonging to Retroviridae family. This study aimed to summarize current information on the epidemiological status of SRLVs infection in the population of goats from Romania and to point out the CAE incidence throughout the 2008-2018 periods.

Materials and Methods: An exhaustive review of the papers published in the international literature concerning the epidemiological status of CAE in Romania was carried out using electronic databases, and available statistical data from the World Organization for Animal Health (OIE) regarding the incidence of the disease between 2008 and 2018 were analyzed.

Results: The true individual-level seroprevalence of CAE was estimated in 13 of 42 counties (31\%) and ranged from $0.4 \%$ to roughly $40 \%$. One hundred eighty-two outbreaks from 14 counties (33\%) were reported, with a peak in 2010.

Conclusion: The findings sourcing in the literature are very scarce and show disagreement with the situation reported by the national veterinary authorities. Lack of SRLVs screening policies represents the main obstacle in limiting the spread of the disease. Romania's National Sanitary Veterinary and Food Safety Authority should implement a program for diagnosis and surveillance of the disease to build a straightforward epidemiological picture that represents a prerequisite of any control and eradication program.
\end{abstract}

Keywords: epidemiology, goat, outbreaks, small ruminant lentivirus.

\section{Introduction}

Caprine arthritis-encephalitis (CAE) is one of the most important viral diseases of goats, which causes significant economic losses all around the world [1]. CAE was first described by Cork et al. [2] in 1974, and the causal agent was first isolated from an arthritic goat by Crawford et al. [3] a few years later. CAE is produced by a single-stranded RNA lentivirus belonging to the family Retroviridae, of the Ortervirales order [4]. CAE virus (CAEV) and Maedi-Visna virus (MVV), both belonging to the genus Lentivirus, are grouped in small ruminant lentiviruses (SRLVs) due to their genomic and antigenic similarities [5]. SRLVs transmission mainly occurs by the ingestion of virus-containing colostrum/milk by the kids, but direct contact with the infected animals (horizontal

Copyright: Potarniche, et al. Open Access. This article is distributed under the terms of the Creative Commons Attribution 4.0 International License (http://creativecommons.org/licenses/ by/4.0/), which permits unrestricted use, distribution, and reproduction in any medium, provided you give appropriate credit to the original author(s) and the source, provide a link to the Creative Commons license, and indicate if changes were made. The Creative Commons Public Domain Dedication waiver (http:// creativecommons.org/publicdomain/zero/1.0/) applies to the data made available in this article, unless otherwise stated. transmission) should also be considered [6-8]. The disease is characterized by a long incubation period and persistent infection. In general, infected animals do not show clinical signs. In animals clinically ill, arthritis, mastitis, and pneumonia are the most frequent signs in adult goats, while kids show neurological signs [9]. The disease spreads subtly in a herd, affecting a high percentage of goats before the first clinical signs can be noticed [10]. Therefore, CAE diagnosis relies on laboratory tests. Even though detecting SRLVs by the use of molecular biology methods (polymerase chain reaction) appear to be a sensitive diagnostic approach, no such tests have been so far introduced in routine practice, and serological assays, such as enzyme-linked immunosorbent assay (ELISA) or agar-gel immunodiffusion (AGID), remain the main tests for CAE diagnosis [11]. Live trade of goats from countries where the disease has been reported is believed to be the main reason for its widespread [6]. At present, there are no treatments or vaccines against CAE. Thus, control programs remain the only way solution to avoid the spreading of SRLVs infection [12].

Little information is available regarding SRLVs infection in goats from Romania. CAE is a 
transmissible disease of goats which is subjected to the internal notification stipulated in Annex no. 1 of the Order of the President of Romania's National Sanitary Veterinary and Food Safety Authority (NSVFSA) no.79/2008. However, no surveillance or diagnosis programs are active at the national level. This is the first study that comes to put together and discusses all the information available on the SRLVs infection in goats from Romania.

The aim of this study was to review the actual epidemiological situation of SRLVs infection in goats in Romania based on scientific literature and to analyze the CAE incidence throughout the 2008-2018 period.

\section{Materials and Methods}

\section{Ethical approval} study.

No ethical approval was needed to perform this

\section{Searching approach}

All the materials published in the international literature concerning the epidemiological status of CAE in Romania were reviewed using search engines such as Web of Science, PubMed, Scopus, ScienceDirect, and Google Scholar. The following keywords were used (alone or in combinations) for this purpose: "CAE," "CAEV," "SRLV," "epidemiology," "prevalence," "seroprevalence," "incidence," "outbreaks," "reports," "detection," "goats," and "Romania." Likewise, the available information from the World Animal Health Information Database (OIE), Food and Agriculture Organization (FAO) of United Nations, and from Romania's NSVFSA was used.

\section{Data extraction}

Data concerning goat characteristics (age, gender, breed, and herds size), samples (size, and specimen), counties investigated (name, and number), diagnostic methods used, and the prevalence (overall, individual-level, and herd-level) were extracted from the studies. Similarly, information about the size of the goat population, number of CAE outbreaks by years, and counties from Romania were collected from OIE, FAO, and NSVFSA databases.

\section{Statistical analysis}

Sensitivity ( $\mathrm{Se}$ ) and specificity ( $\mathrm{Sp}$ ) of diagnostic tests used for the detection of SRLVs infection were based on so far published studies. When compared to the western-blotting, Se and Sp of AGID are roughly $76 \%$ and $98 \%$, respectively [13], and its lower than for the whole-virus ELISA, which has Se and Sp of roughly $98 \%$ [14]. On the basis of these figures, the true seroprevalence was calculated using the Rogan-Gladen equation [15]. The $95 \%$ confidence intervals (CI) were calculated with the Wilson score method [16].

\section{Results}

Only five studies regarding the occurrence of SRLV infection in goats in Romania have been published [17-21]. All of them were serological surveys, and three were carried out with the use of AGID test [18-20], and two with the use of the whole-virus ELISA [17,21].

Gurau et al. [17] tested 78 goats from a single herd counting 120 goats, located in the Braila County using an indirect ELISA kit (IDEXX CAEV/MVV Total Ab Test, Switzerland). Thirty tested positive, which yielded a true individual-level seroprevalence of $38.0 \%$ (CI 95\%: 28.0\%, 49.1\%). Similarly, Mihai et al. [18] screened a 400-French Alpine goat herd from Vaslui County with AGID (CAEV-p28 AGID diagnostic kit, Pourquier-Montpellier, France). Ninety-four of 295 serum samples tested were positive, and the true individual-level seroprevalence was 40.4\% (CI 95\%: 34.9\%, 46.0\%). In the second study, the same authors screened a group of 412 symptomatic and asymptomatic goats from four Romanian counties. Of them, 94 tested positive in AGID test, resulting in a true individual-level seroprevalence of $28.1 \%$ $(24.0 \%$, and $32.7 \%)$ [19]. In a 3-year survey study in Sibiu county, Potarniche et al. [20] tested 15947 sera with AGID (Pourquier-Montpellier, France). An overall true individual-level seroprevalence ranged from $0.4 \%(\mathrm{CI} 95 \%: 0.3 \%, 0.6 \%)$ in the $1^{\text {st }}$ year to $9.1 \%$ (CI 95\%: 8.5\%, 10.7\%) in the last year. Another study was conducted by Enache et al. [21], which tested 47 pooled samples (from 235 goats) originating from nine Romanian counties using a commercial ELISA kit (IDEXX CAEV/MVV Total Ab Test, Switzerland). The pooled sera were created by mixing $100 \mu \mathrm{l}$ of serum from five animals from the same herd. Positive results were obtained for pooled samples from four counties (Dambovita, Ilfov, Braila, and Constanta). The results were variable from region to region with an overall seroprevalence of $21.3 \%$. In none of these larger studies [19-21], the number of goat herds tested was mentioned. In total, 13 counties had been investigated, and the presence of the disease was reported in six of them (46\%) (Figure-1 and Table-1) [17-21].

The number of official outbreaks of CAE from Romania was quantified based on the data from

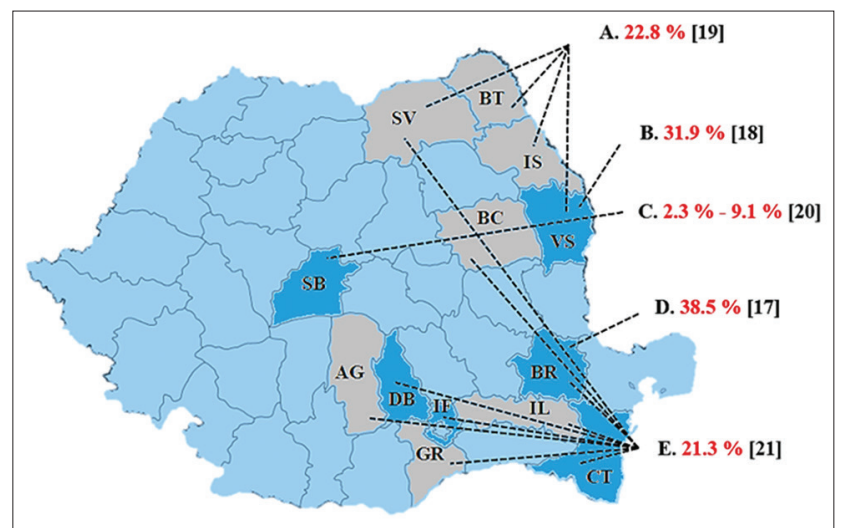

Figure-1: Map of the surveyed Romanian counties and the apparent seroprevalence of caprine arthritis-encephalitis. Counties: $A G=$ Arges, $B C=$ Bacau, $B R=$ Braila, $B T=$ Botosani, $\mathrm{CT}=$ Constanța, $\mathrm{DB}=$ Dimbovita, $\mathrm{GR}=$ Giurgiu, $\mathrm{IF}=\mathrm{Ilfov}$, $\mathrm{IL}=$ Ialomita, IS=Iasi, SB=Sibiu, SV=Suceava, VS=Vaslui. 


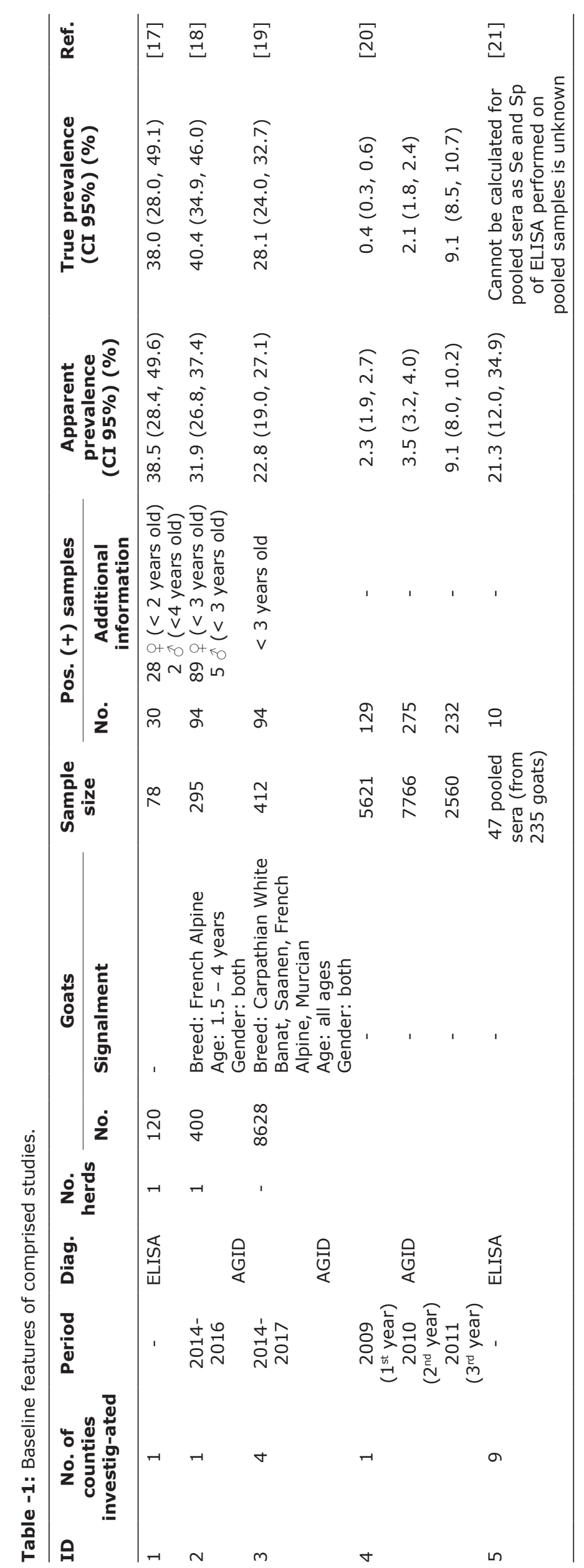


OIE [22], which basically represents the result of serological investigations carried out by territorial structures of NSVFSA [23] after clinical cases of CAE have been suspected and reported by local veterinarians. The results regarding the incidence of CAE outbreaks in Romania according to the OIE are presented briefly in Figures-2-5. The first outbreak was noticed

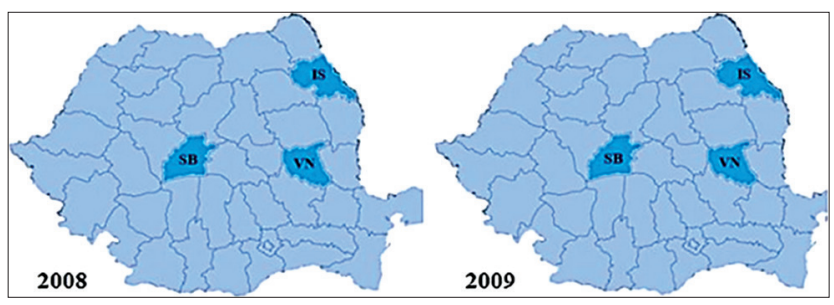

Figure-2: Distribution of the reported caprine arthritisencephalitis outbreaks in Romania between 2008 and 2009. Counties: IS=Iasi, SB=Sibiu, VN=Vrancea.

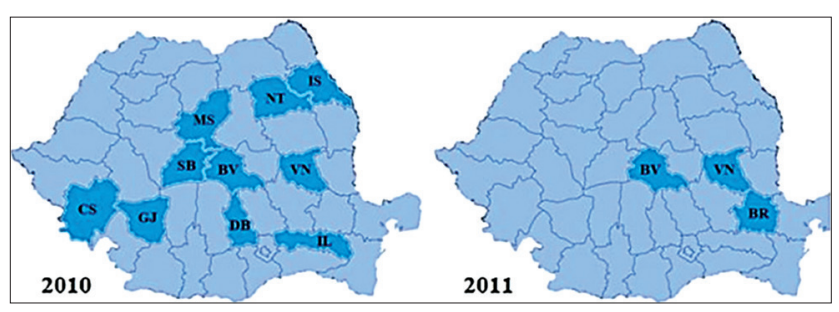

Figure-3: Distribution of the reported caprine arthritisencephalitis outbreaks in Romania between 2010 and 2011. Counties: $B R=B r a i l a, B V=B r a s o v, C S=$ Caras-severin, $\mathrm{DB}=$ Dimbovita, $\mathrm{G}]=$ Gorj, IL=Ilfov, IS=Iasi, $M=$ Mures, $\mathrm{NT}=$ Neamt, $\mathrm{SB}=$ Sibiu, $\mathrm{VN}=$ Vrancea.

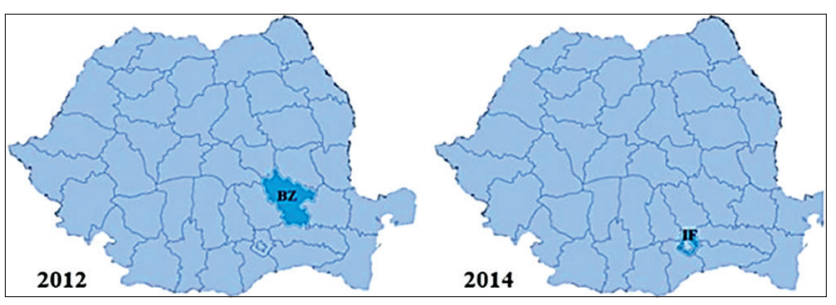

Figure-4: Distribution of the reported caprine arthritisencephalitis outbreaks in Romania between 2012 and 2014. Counties: $B Z=B u z a u, I F=I l f o v$.

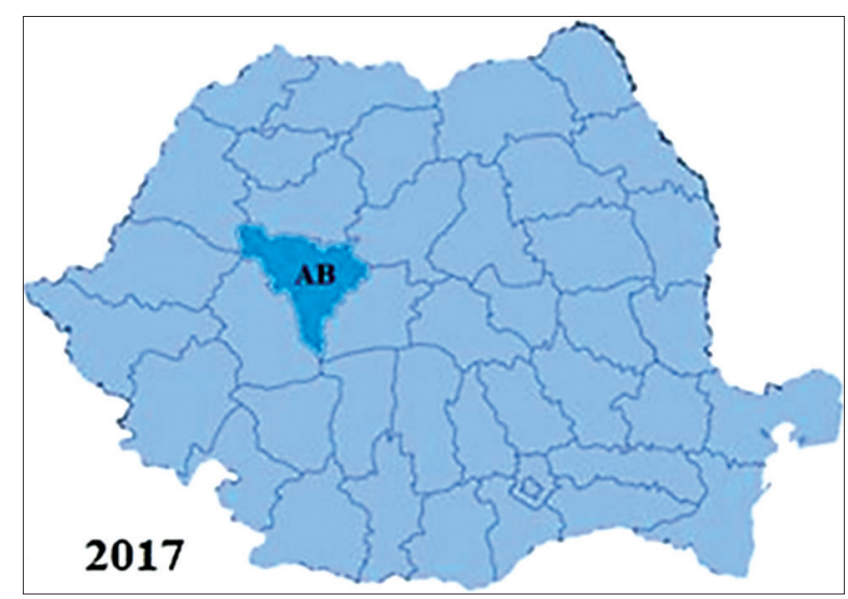

Figure-5: Distribution of the reported caprine arthritisencephalitis outbreaks in Romania during 2017. Counties: $\mathrm{AB}=$ Alba. in 2008, in Sibiu County. Then, six more outbreaks were reported in the same county, with 49 cases of CAE confirmed using AGID. During the subsequent years, more and more outbreaks emerged in the whole country. The highest number of disease outbreaks was recorded in 2010 when a number of ten counties were involved. The last outbreak was reported at the beginning of the year 2017 in Alba-Iulia, where four goats were found to be positive after serological investigation (AGID). During 2013, 2015, 2016, and 2018, no CAE outbreaks were reported. Thus, throughout the 2008-2018 period, the disease was reported in 14 counties (33\%) from Romania that yields 182 outbreaks (Table-2).

\section{Discussion}

Under these circumstances, it is difficult to define the real epidemiological status of CAE in Romania given the low number of counties investigated $(31 \%)$. Furthermore, the number of herds and individual goats that were taken into account was low in certain counties, only one herd being investigated. The overall seroprevalence of SRLVs infection in goats has been reported in several countries. Similar seroprevalence $(2.9-38.5 \%)$ that the ones reported in Romania were found in India (3.3\%) [24], Oman (5.1\%) [25], Sudan (5.8\%) [26], Belgium (6\%) [27], Malaysia (8.9\%) [28], Japan (10\%) [29], Liban (13.1\%) [30], Kosovo (15.6\%) [31], Italy (18.6\%) [32], and Algeria (29.7\%) [33]. Lower seroprevalence was reported in Switzerland (0.06\%) [34] and higher in Brazil (49.5\%) [35], Poland (51.6\%) [36], Croatia (53.7\%) [37], and Taiwan (61.7\%) [38].

According to Enache et al. [39] between 2006 and 2015, Romania had the highest number of CAE serological positive results reported in the whole Europe. In this regard, there are numerous factors that can influence the emergence of new outbreaks.

First of all, the low number of SRLVs outbreaks in some European countries was correlated with the existence of control and eradication programs. Moreover, management practices affect the prevalence of SRLVs in a herd. Therefore, control programs have been implemented in many countries since SRLVs were detected in their goat herds [40]. For example, Switzerland began a voluntary SRLVs eradication program in 1984, and in 1998 was recognized as a "CAE-free" country [6]. Similarly, Norway initiated programs aiming to eradicate the SRLVs infection $[41,42]$. Although CAE represents a disease subject to internal notification, no surveillance or diagnosis programs are currently implemented in Romania. Singularly, an active surveillance program was applied in 2010 due to the Order of the President of NSVFSA no.2/2010, which can explain the large number of outbreaks found during that year. According to it, $2 \%$ of goats from each herd were randomly tested. In Romania, both serological tests, AGID and ELISA are used as confirmatory methods by accredited 
Table-2: The incidence of CAE outbreaks in Romanian counties throughout 2008-2018 period.

\begin{tabular}{|c|c|c|c|c|c|c|c|c|c|c|c|c|}
\hline \multirow{2}{*}{$\begin{array}{l}\text { Location } \\
\text { (counties) }\end{array}$} & \multicolumn{11}{|c|}{ Years } & \multirow[t]{2}{*}{ Total } \\
\hline & 2008 & 2009 & 2010 & 2011 & 2012 & 2013 & 2014 & 2015 & 2016 & 2017 & 2018 & \\
\hline Alba & & & & & & & & & & 1 & & 1 \\
\hline Braila & & & & 1 & & & & & & & & 1 \\
\hline Brasov & & & 3 & 1 & & & & & & & & 4 \\
\hline Buzau & & & & & 1 & & & & & & & 1 \\
\hline Caras-Severin & & & 7 & & & & & & & & & 7 \\
\hline Dimbovita & & & 9 & & & & & & & & & 9 \\
\hline Gorj & & & 11 & & & & & & & & & 11 \\
\hline Ialomita & & & 13 & & & & & & & & & 13 \\
\hline Iasi & 1 & 5 & 2 & & & & & & & & & 8 \\
\hline Mures & & & 1 & & & & & & & & & 1 \\
\hline Neamt & & & 64 & & & & & & & & & 64 \\
\hline Sibiu & 7 & 1 & 14 & & & & & & & & & 22 \\
\hline Vrancea & 15 & 6 & 16 & 2 & & & & & & & & 39 \\
\hline Ilfov & & & & & & & 1 & & & & & 1 \\
\hline Total (14) & 23 & 12 & 140 & 4 & 1 & & 1 & & & 1 & & 182 \\
\hline
\end{tabular}

laboratories [23]. Concisely, the following practices are recommended to be applied in SRLVs infected goat herds: (a) Permanent isolation of kids immediately after birth; (b) feeding of heat-treated colostrum $\left(45^{\circ} \mathrm{C}\right.$ for $\left.60 \mathrm{~min}\right)$; (c) serological examination of the herd (twice per year) and maintaining the seronegative and seropositive goats separately; and (4) culling of seropositive goats $[8,40]$.

The size of the goat population and the live animal trade represents other possible factors affecting the epidemiology of CAE. The goat population from Romania has increased every year, reaching 1.5 million goats in 2017. It is one of the biggest population of goats from Europe after Russia (2 mils), Spain (3.1 mils), and Greece (6.3 mils) [43]. In Romania, the imports of live sheep and goats from the intra-community area have increased in the period 2010-2014 by 9.3 times [44]. In recent years, imports of goats from breeds specialized in milk production, such as Saanen and French Alpine have increased in Romania. The animals were brought from different countries such as France or even New Zeeland, which are not free of SRLVs infection [19]. By comparison, looking at a Polish herd where the prevalence has increased from $15 \%$ to $75 \%$, after the importation of dairy goats from France during the 1990s [6,8], we can presume the importation of goats to Romania as one of the causes of the latter increase in CAE prevalence. The virus is hardly found in native breeds unless they were exposed or had direct contact with imported goats [24]. Thus, the regulations regarding the live trade of goats stipulated in the national strategic program (Order of the President of NSVFSA no.35/2016) should be implemented very strictly to minimize the importation of infected animals.

Another critical aspect of the spreading of the virus is the cohabitation of sheep with goats. In Romania, farmers mostly keep both species together in the same shed or in close contact. Commonly, during the summer, sheep, and goats share grazing areas and water sources. This can increase the risk of SRLVs interspecies transmission. Phylogenetic analysis of SRLVs revealed that different SRLVs strains could be transmitted naturally and experimentally from sheep to goats and vice-versa $[45,46]$. Consequently, mixed farms of goats and sheep may represent an active source for the evolution of these viruses [47]. Therefore, the eradication programs implemented in both species could help in controlling the disease [48]. Moreover, recent studies have identified SRLVs in wild ruminants, which may also contribute to SRLVs epidemiology [49]. Likewise, the slow natural spread of the virus, the absence of clinical signs, or their misinterpretation by veterinarians can lead to unreported outbreaks.

\section{Conclusion}

The available information regarding the situation of CAE in Romania is very scarce. There are only a few studies about the prevalence of CAE, therefore offering an incomplete picture of the actual status of the disease. The presence of the disease in the country is also confirmed by the last reported outbreaks. Lack of SRLVs screening policies represents the main obstacle in limiting the spread of the disease. However, SRLVs infection often shows a complex scenario. The infection is frequently subclinical, SRLVs are genetically related, and interspecies transmission is possible. Therefore, knowing the epidemiological dynamics, the need for surveillance of SRLVs infection remains a longstanding task. Romanian national veterinary authorities should implement a program for diagnosis and surveillance to build a straightforward epidemiological picture that represents a precondition of any control and eradication program.

\section{Authors' Contributions}

AVP designed the study, contributed to literature collection, prepared the figures/tables, and wrote the manuscript draft alongside with CGC. MC performed the statistical and epidemiological analyses. OS and MS critically revised the manuscript. JK 
provided conceptual support and critically reviewed the manuscript. All authors read, revised, and approved the final manuscript.

\section{Acknowledgments}

The authors are thankful to Dr. Velizar Barbuli, the director of Romania's National Sanitary Veterinary and Food Safety Authority for all the information provided. The publishing charge was sponsored by University of Agricultural Sciences and Veterinary Medicine Cluj-Napoca, Romania. The authors did not receive any funds for this study.

\section{Competing Interests} interests.

The authors declare that they have no competing

\section{Publisher's Note}

Veterinary World remains neutral with regard to jurisdictional claims in published map and institutional affiliation.

\section{References}

1. Smith, M.C. and Sherman, D.M. (2009) Goat Medicine. $2^{\text {nd }}$ ed. Wiley-Blackwell, Iowa, USA. p96-106.

2. Cork, L.C., Hadlow, W.J., Crawford, T.B., Gorham, J.R. and Piper, R.C. (1974) Infectious leukoencephalomyelitis of young goats. J. Infect. Dis., 129(2): 134-141.

3. Crawford, T.B., Adams, D.S., Cheevers, W.P. and Cork, L.C. (1980) Chronic arthritis in goats caused by a retrovirus. Science, 207(4434): 997-999.

4. International Committee on Taxonomy of Viruses. (2018) Virus Taxonomy: 2018b Release. Available from: https://www.talk.ictvonline.org/taxonomy. Retrieved on 05-11-2019.

5. Barquero, N., Arjona, A., Domenech, A., Toural, C., De Las Heras, A., Fernandez-Garayzabal, J. F., Quiteria, J. A. R. and Gomez-Lucia, E. (2011) Diagnostic performance of PCR and ELISA on blood and milk samples and serological survey for small ruminant lentiviruses in central Spain. Vet. Rec., 168(1): 20.

6. Animal and Plant Health Inspection Service. (2008) Caprine Arthritis Encephalitis Virus. United States Department of Agriculture, Maryland, USA.

7. Pugh, D.G., Baird, A.N., Edmondson, M. and Passler, T. (2020) Sheep, Goat and Cervid Medicine. $3^{\text {rd }}$ ed. Elsevier, Philadelphia, USA. p726-729.

8. Balbin, M.M. and Mingala, C.N. (2017) Caprine arthritis-encephalitis. In: Bayry, J., editor. Emerging and Re-emerging Infectious Diseases of Livestock. Springer, Paris, France. p191-213.

9. World Organization for Animal Health. (2017) Manual of Diagnostic Tests and Vaccine for Terrestrial Animals. $7^{\text {th }}$ ed. World Organization for Animal Health, Paris, France. p1-10.

10. Czopowicz, M., Szalus-Jordanow, O., Mickiewicz, M., Moroz, A., Witkowski, L., Morkowska-Daniel, I., Reczynska, D., Bagnicka, E. and Kaba, J. (2018) Decline of maternal antibodies to small ruminant lentivirus in goat kids. Anim. Sci. J., 89(9): 1364-1370.

11. Herrmann-Hoesing, L.M. (2010) Diagnostic assays used to control small ruminant lentiviruses. J. Vet. Diagn. Invest., 22(6): 843-855.

12. Minguijon, E., Reina, R., Perez, M., Polledo, L., Villoria, M., Ramirez, H., Leginagoikoa, I., Badiola, J.J., GarciaMarin, J.F., de Andres, D., Lujan, L. and Amorena, J.R.A. (2015) Small ruminant lentivirus infections and diseases.
Vet. Microbiol., 181(1-2): 75-89.

13. Varea, R., Monleon, E., Pacheco, C., Lujan, L., Bolea, R., Vargas, M.A., van Eynde, G., Saman, E., Dickson, L., Harkiss, G.D., Amorena, B. and Badiola, J.J. (2001) Early detection of maedi-visna (ovine progressive pneumonia) virus seroconversion in field sheep samples. J. Vet. Diagn. Invest., 13(4): 301-307.

14. Heckert, R.A., McNab, W.B., Richardson, S.M. and Briscoe, M.R. (1992) Evaluation of an enzyme-linked immunosorbent assay for the detection of antibodies to caprine arthritis-encephalitis virus in goat serum. Can. J. Vet. Res., 56(3): 237-241.

15. Rogan, W.J. and Gladen, B. (1978) Estimating prevalence from the results of a screening test. Am. J. Epidemiol., 107(1): 71-76.

16. Altman, D.G., Machin, D., Bryant, T.N. and Gardner, M.J. (2000) Statistics with Confidence. $2^{\text {nd }}$ ed. BMJ Books, London.

17. Gurău, M.R., Baraitareanu, S. and Daneș, D. (2015) Serological survey of caprine arthritis-encephalitis virus infection in a Southeastern Romanian farm. Sci. Works Ser. C Vet. Med., 61(2): 169-171.

18. Mihai, I., Crivei, I.C., Horhogea, C., Savuța, G. and Velescu, E. (2018) Preliminary serological investigation on caprine arthritis and encephalitis virus infection in a goat Farm from North-Eastern Romanian Region. Bull. UASVM Vet. Med., 75(2): 243-245.

19. Mihai, I., Velescu, E. and Tanase, O.I. (2018) Epidemiological observations on infectious pathology of goats in the Northeast area of Romania. Agriculture for Life, Life for Agriculture, Conference Proceedings, 1(1): 449-454.

20. Potârniche, A.V., Cerbu, C., Olah, D., Suatean, M., Peredi, C., Guranda, S. and Spînu, M. (2018) Serological survey of caprine arthritis-encephalitis virus infection in Sibiu county, Romania. Sci. Works Ser. C Vet. Med., 64(2): 70-72.

21. Enache, D.A., Baraitareanu, S., Dan, M., Gurau, M.R., Otelea, F., Dobre, A. and Danes, D. (2017) Preliminary results of MVV and CAEV seroprevalence in Romanian sheep and goats. Sci. Works Ser. C Vet. Med., 63(1): 95-100.

22. World Organization for Animal Health. (2019) World Animal Health Information Database (WAHIS Interface). World Organization for Animal Health, Paris, France. Available from: http://www.oie.int. Retrieved on 10-12-2019.

23. National Sanitary Veterinary and Food Safety Authority of Romania. Bucharest, Romania. Available from: http://www. ansvsa.ro/en. Retrieved on 15-12-2019.

24. Waseem, A., Pawaiya, R.V.S., Singh, R., Gupta, V.K., Rajukumar, K., Mir, M.S. and Aamir, S. (2015) Seroprevalence of caprine arthritis encephalitis virus infection (CAEV) in Indian goats. Indian J. Vet. Pathol., 39(1): $11-15$.

25. Tageldin, M.H., Johnson, E.H., Al-Busaidi, R.M., Al-Habsi, K.R. and Al-Habsi, S.S. (2012) Serological evidence of caprine arthritis-encephalitis (CAEV) infection in indigenous goats in the Sultanate of Oman. Trop. Anim. Health Prod., 44(1): 1-3.

26. Elfahal, A.M., Hussien, M.O., Enan, K.A., Taha, K.M., Salih, D.A., Halfawi, R.H., Mohammed, Z.A. and El-Hussein, A.M. (2013) Investigation of caprine arthritis-encephalitis virus in Sudan using competitive enzymelinked immunosorbent assay. Vet. World., 6(8): 558-562.

27. Michiels, R., Van Mael, E., Quinet, C., Welby, S., Cay, A.B. and De Regge, N. (2018) Seroprevalence and risk factors related to small ruminant lentivirus infection in Belgian sheep and goats. Prev. Vet. Med., 151(March): 13-20.

28. Jesse, F.F.A., Bitrus, A.A., Abba, Y., Raju, V.N., Hambali, I.U., Peter, I.D., Haron, A.W., Lila, M.A.M. and Norsidin, J.M. (2018) Seroprevalence of small ruminant caprine arthritis encephalitis lentivirus among goats from selected small ruminant farms in Selangor, Malaysia. Vet. 
World, 11(2): 172-176.

29. Konishi, M., Hayama, Y., Shirafuji, H., Kameyama, K.I., Murakami, K., Tsutsui, T. and Akashi, H. (2016) Serological survey of caprine arthritis-encephalitis virus infection in Japan. J. Vet. Med. Sci., 78(3): 447-450.

30. Tabet, E., Hosri, C. and Abi-Rizk, A. (2015) Caprine arthritis encephalitis virus: Prevalence and risk factors in Lebanon. Rev. Sci. Tech., 34(3): 915-921.

31. Cana, A., Taylor, N., Honhold, N., Gjinovici, V., Osmani, A., Nardelli, S., Murati, B., Spahrj, J., Mehmetukaj, D. and Alishani, M. (2020) Seroprevalence survey of small ruminant lentivirus (SRLV) infections in Kosovo. Kafkas. Univ. Vet. Fak. Derg., 26(1): 1-8.

32. Cirone, F., Maggiolino, A., Cirilli, M., Sposato, A., De Palo, P., Ciappetta, G. and Pratelli, A. (2019) Small ruminant lentiviruses in goats in southern Italy: Serological evidence, risk factors and implementation of control programs. Vet. Microbiol., 228(January): 143-146.

33. Idres, T., Lamara, A., Temim, S., Boudjellaba, S., Gagnon, J. and Chebloune, Y. (2019) Serological diagnosis of lentivirus infection in goats raised in Algeria. J. Vet. Res., 63(1): 27-33.

34. Thomann, B., Falzon, L.C., Bertoni, G., Vogt, H.R., Schupback-Regula, G. and Magouras, I. (2017) A census to determine the prevalence and risk factors for caprine arthritis-encephalitis virus and visna/maedi virus in Swiss goat population. Prev. Vet. Med., 137(Pt A): 52-58.

35. Nascimento-Penido, P.M.P., Penido, A.O., Galinari, G.N.F., Heinemann, M.B. and Leite, R.C. (2017) Occurrence of caprine arthritis encephalitis virus (CAEV) in dairy goats produced in an intensive confined system in the state of Minas Gerais, Brazil. Pesquisa Vet. Bras., 37(6): 577-581.

36. Gruszecki, T.M., Olech, M., Kuzmak, J., Bagnicka, E., Szymanowska, A., Szczepaniak, K., Gregula-Kania, M., Tomczuk, K. and Bojar, W. (2018) Prevalence of CAEV infections in goat herds. Med. Weter., 74(8): 536-539.

37. Tariba, B., Kostelic, A., Roic, B., Benic, M. and Salamon, D. (2017) Influence of caprine arthritis encephalitis virus infection on milk production of French alpine goats in Croatia. Mljekarstvo, 67(1): 42-48.

38. Yang, W.C., Chen, H.Y., Wang, C.Y., Pan, H.Y., Wu, C.W., Hsu, Y.H., Su, J.C. and Chan, K.W. (2017) High prevalence of caprine arthritis encephalitis virus (CAEV) in Taiwan revealed by large-scale serological survey. J. Vet. Med. Sci., 79(2): 273-276.

39. Enache, D.A., Baraitareanu, S. and Danes, D. (2016) The incidence of SRLVs infection in European countries over the 10 year period, 2006 to 2015. J. Int. Sci. Public., 4(1): 518-529.

40. Peterhans, E., Greenland, T., Badiola, J., Harkiss, J., Bertoni, G., Amorena, B., Eliaszewicz, M., Juste, R.A., Krassnig, R., Lafont, J.P., Lenihan, P., Petursson, G., Pritchard, G., Thorley, J., Vitu, C., Mornex, J.F. and Pepin, M. (2004) Routes of transmission and consequences of small ruminant lentiviruses (SRLVs) infection and eradication schemes. Vet. Res., 35(3): 257-274.

41. TINE. (2013) Disease Eradication on Norwegian Goats. Available from: http://www.geithelse.tine.no/english. Retrieved on 24-12-2019.

42. Nagel-Alne, G.E., Valle, P.S., Krontveit, R. and Solverod, L.S. (2015) Caprine arthritis encephalitis and caseous lymphadenitis in goats: Use of bulk tank milk ELISAs for herd-level surveillance. Vet. Rec., 176(7): 173.

43. Food and Agriculture Organization of United Nations. Available from: http://www.fao.org. Retrieved on 24-12-2019.

44. Grodea, M. and Ionel, I. (2015) The Romanian export with livestocks of live animals a far reaching activity? In: Agricultural Economics and Rural Development Realities and Perspectives for Romania. $6^{\text {th }} \mathrm{ed}$. University Library of Munich, Germany. p23-28.

45. Shah, C., Böni, J., Huder, J.B., Vogt, H.R., Mühlherr, J., Zanoni, R., Miserez, R., Lutz, H. and Schüpbach, J. (2004) Phylogenetic analysis and reclassification of caprine and ovine lentiviruses based on 104 new isolates: Evidence for regular sheep-to-goat transmission and worldwide propagation through livestock trade. Virology, 319(1): 12-26.

46. Maclachlan, N.J. and Dubovi, E.J. (2017) Fenner's Veterinary Virology: Retroviridae. $5^{\text {th }}$ ed. Academic Press, London, UK. p270-297.

47. Fras, M., Lebouf, A., Labrie, F.M., Laurin, M.A., Sohal, J.S. and L'Homme, Y. (2013) Phylogenetic analysis of small ruminant lentiviruses in mixed flocks: Multiple evidence of dual infection and natural transmission of Types A2 and B1 between sheep and goats. Infect. Genet. Evol., 19(October): 97-104.

48. Pisoni, G., Quasso, A. and Moroni, P. (2005) Phylogenetic analysis of small ruminant lentivirus subtype B1 in mixed flocks: Evidence for natural transmission from goats to sheep. Virology, 339(2): 147-152.

49. Olech, M., Osinski, Z. and Kuzmak, J. (2020) Seroprevalence of small ruminant lentivirus (SRLV) infection in wild cervids in Poland. Prev. Vet. Med., 176(March): 1-7. 